\title{
Development and validation of a microbiological assay for determination of chlorhexidine digluconate in aqueous solution
}

\author{
Flávia Angélica Másquio Fiorentino, Marcos Antonio Corrêa, Hérida Regina Nunes Salgado*
}

Department of Drugs And Medicines, School of Pharmaceutical Sciences, University Estadual Paulista

\begin{abstract}
Chlorhexidine ( $\mathrm{CHX})$ is a broad-spectrum antiseptic that is used in many topical pharmaceutical formulations. Because there is no official microbiological assay reported in the literature that is used to quantify $\mathrm{CHX}$, this paper reports the development and validation of a simple, sensitive, accurate and reproducible agar diffusion method for the dosage of chlorhexidine digluconate (CHX-D) in an aqueous solution. The assay is based on the inhibitory effect of CHX-D upon the strain of Staphylococcus aureus ATCC 25923, which is used as the test microorganism. The design 3x3 parallel-line model was used. The results were treated statistically by analysis of variance (ANOVA), and they were excellent in terms of linearity $(r=0.9999)$, presenting a significant regression between the zone diameter of growth inhibition and the logarithm of the concentration within the range of 0.5 to $4.5 \%$. The results obtained were precise, having relative standard deviations (RSD) for intra-day and inter-day precision of $2.03 \%$ and $2.94 \%$, respectively. The accuracy was $99.03 \%$. The method proved to be very useful and appropriate for the microbiological dosage of CHX-D in pharmaceutical formulations; it might also be used for routine drug analysis during quality control in pharmaceutical industries.
\end{abstract}

Uniterms: Agar diffusion. Antiseptic. Chlorhexidine. Microbiological assay. Quality control. Validation.

Clorexidina (CHX) é um antisséptico com amplo espectro de ação utilizada em muitos tipos de preparações farmacêuticas para uso tópico. Uma vez que não há na literatura ensaio microbiológico oficial para quantificar a clorexidina, este trabalho objetivou o desenvolvimento e validação de um ensaio microbiológico simples, sensível, exato e reprodutível, por difusão em ágar, para doseamento de digliconato de clorexidina (CHX-D) em solução aquosa. O ensaio é baseado no efeito da inibição de Staphylococcus aureus ATCC 25923, utilizado como microorganismo teste, pela CHX-D. Utilizouse o delineamento $3 \times 3$. Os resultados foram verificados estatisticamente pela análise de variância (ANOVA) e apresentaram excelente linearidade $(\mathrm{r}=0,9999)$, demonstrando que o método segue o modelo linear com regressão significativa entre o diâmetro da zona de inibição e o lagaritmo da concentração no intervalo de 0,5 a 4,5\%. Os resultados obtidos foram precisos apresentando desvio padrão relativo (DPR) para precisão intra-dia de 2,03\% e DPR para precisão inter-dias de $2,94 \%$. A exatidão foi $99,03 \%$. O método provou ser muito útil e apropriado para doseamento microbiológico da CHX-D em formas farmacêuticas e pode ser empregado para análise desta substância no controle de qualidade em indústrias farmacêuticas.

Unitermos: Difusão em ágar. Antisséptico. Clorexidina. Ensaio microbiológico. Controle de qualidade. Validação.

\section{INTRODUCTION}

Antiseptics are products that are used to clean and disinfect traumatic wounds, burns, mucous membranes,

*Correspondence: H. R. N. Salgado. Universidade Estadual Paulista. Rodovia Araraquara-Jaú, km 1, 14801-902 - Araraquara - SP, Brasil. Phone: 55-16-33016967, Fax 55-16-33016900. E-mail: salgadoh@fcfar.unesp.br hands, and surgical sites and are sometimes used to impregnate catheters (Fiorentino, Corrêa, Salgado, 2010).

Chlorhexidine (CHX) is an excellent cationic antiseptic that belongs to a class of drugs called biguanides and has the chemical name $(1,1$ '-hexamethylenebis $\{5$ ( $p$-chlorophenyl)biguanide) $\}$ (Buxbaum et al., 2006; USP, 2008; BP, 2010; EP, 2011). It exists as a variety of salts, including acetate, gluconate, hydrochloride 
and digluconate, but the digluconate form (Figure 1) is the most soluble in water and at physiological $\mathrm{pH}$ (EP, 2011; Thomas et al., 2000; Martindale, 2009). CHX is active against Gram-positive bacteria; less active against Gram-negative bacteria, fungi, and species of Proteus; and has activity against certain types of enveloped viruses, including hepatitis virus, herpes simplex, HIV, cytomegalovirus, influenza and respiratory syncytial virus. For mycobacteria, the CHX exhibits minimal activity; against endospores and cysts of protozoa the activity is nil (Fiorentino, Corrêa, Salgado, 2010; Cone et al., 2006; Martindale, 2009).

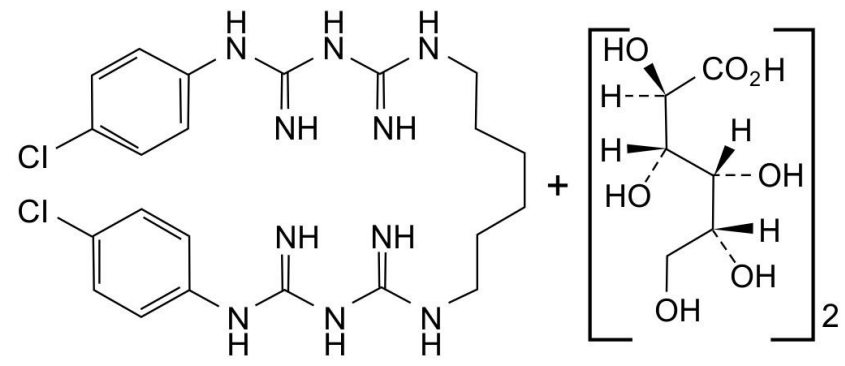

FIGURE 1 - Chemical structure of chlorhexidine digluconate (CAS: 18472-51-0).

There are many uses for CHX. It is most likely the most widely used biocide in antiseptic products, specifically in hand-washing and oral products; it is also used to impregnate catheters or other medical products, as a preservative in vaginal gel, as a disinfectant (Cone et al., 2006; Galice et al., 2006) and as a surgical scrub to clean the site of surgery (Buxbaum et al., 2006).

Standard physicochemical methods for the determination of CHX are described in the European, British and United States Pharmacopoeias (USP, 2008; BP, 2010; EP, 2011). These techniques employ high performance liquid chromatography (HPLC) (USP, 2008; $\mathrm{BP}, 2010$; EP, 2011) or titration with $0.1 \mathrm{M}$ perchloric acid (BP, 2010; EP, 2011). The methods described in the literature to analyse degradation products of $\mathrm{CHX}$ and related substances are HPLC (USP, 2008) and colorimetric tests (BP, 2010; EP, 2011).

The literature describes several methods for the determination of $\mathrm{CHX}$ in biological fluids, which include direct UV spectroscopy (Jensen, Christensen, 1971), fluorometry (Vries, Ruben, Arends, 1991), HPLC (Gaffney, Cooke, 1984; Brougham, Cheng, Pittman, 1986; Lam et al., 1993; Pesonem, Holmalahti, Pohjola, 1995; Below, Lehan, Kramer, 2004) and liquid chromatographyelectrospray ionisation mass spectrometry (LC-ESI-MS) (Usui et al., 2006). For pharmaceutical products that contain CHX, several physicochemical methods are presented, such as HPLC (Gavlick, 1992; Há, Cheung, 1996; Izumoto et al., 1997; Havlíková et al., 2007), solidphase extraction with UV spectrophotometry (Bonazzi et al., 1995), gas-liquid chromatography (Miribel et al., 1983), and capillary electrophoresis (Abad-Villar et al., 2006).

A standard microbiological assay has not been reported to determine the potency of $\mathrm{CHX}$ digluconate in an aqueous solution using an agar diffusion test. However, in the literature, there are a large number of reports describing the use of microbiological assays to assess the potency of many antibiotics (Marona, Schapoval, 1998; Mendez et al., 2005; Gomes, Salgado, 2006; Salgado, Lopes, Lucchesi, 2006; Vaugher, Breier, Schapoval, 2006; Souza et al., 2007; Moreno, Salgado, 2007; Salgado, Tozo, 2007; Schmidt et al., 2008; Lopes, Salgado, 2010; Cazedey, Salgado, 2011; Paim et al., 2011; Solano et al., 2011).

Although biological assays have a high variability, a microbiological assay can reveal subtle changes that are not demonstrable by chemical methods. A bioassay is an environmentally friendly technique because it does not require solvent or produce toxic by-products. Moreover, a microbiological assay requires no specialised equipment, is low in cost, is a simple procedure and requires only a simple facility to obtain results. These factors make the use of microbiological assays a very good alternative methodology for a potency assessment of antimicrobial drugs in a quality control laboratory (Salgado, Lopes, Lucchesi, 2006; Vaugher, Breier, Schapoval, 2006; Souza et al., 2007; Schmidt et al., 2008; Lopes, Salgado, 2010; Paim et al., 2011). Additionally, the excipients used for physicochemical techniques often cause interference and require expensive and sophisticated equipment that is not available in some quality control laboratories (Schmidt et al., 2008).

The aim of the present study was to develop and validate a simple, sensitive, precise and accurate microbiological assay by agar diffusion using a template method to quantify CHX-D in aqueous solution as an ecological alternative to the physicochemical methods described in the literature.

\section{MATERIAL AND METHODS}

\section{Chemicals}

The CHX digluconate aqueous standard solution (purity $20.0 \%$, batch number: 07/1306) was kindly donated by Rioquímica LTDA (Brazil). The CHX digluconate aqueous solution (Henrifarma ${ }^{\circledR}$, Brazil) (rotulated purity 
$20.0 \%$, batch number: CS 0120705) was kindly donated by the Cosmetology Laboratory of Universidade Estadual Paulista (UNESP) (Brazil). Purified water was used in all experiments.

\section{Preparation of solutions}

\section{Chlorhexidine digluclonate reference solutions}

Aliquots of $250 \mu \mathrm{L}, 750 \mu \mathrm{L}$ and $2250 \mu \mathrm{L}$ of the aqueous CHX digluconate reference solution were transferred to $10-\mathrm{mL}$ volumetric flasks, which were filled with water to give concentrations of $0.5,1.5$ and $4.5 \%$ (S1, S2 and S3), respectively. These standard solutions were used in the bioassay.

\section{Preparation of the sample solutions}

Aliquots of $250 \mu \mathrm{L}, 750 \mu \mathrm{L}$ and $2250 \mu \mathrm{L}$ of a $\mathrm{CHX}$ digluconate aqueous solution were transferred to $10-\mathrm{mL}$ volumetric flasks, which were filled with water to give concentrations of $0.5,1.5$ and $4.5 \%$ (T1, T2 and T3), respectively. These standard solutions were tested against $\mathrm{S} 1, \mathrm{~S} 2$ and S3.

\section{Microorganism and inoculum standardisation}

The cultures of $S$. aureus ATCC 25923 were cultivated on casein-soy agar (Acumedia ${ }^{\circledR}$ ) at a temperature near freezing $\left(2.0\right.$ to $\left.8.0^{\circ} \mathrm{C}\right)$. The microorganism standardisation was carried out according to the procedures described in the Brazilian and United States Pharmacopoeias (USP, 2008; F. BRAS., 2010). Prior to use, the microorganism was grown in Brain Heart Infusion (BHI) broth $\left(\mathrm{BD}^{\circledR}\right)$ in a test tube that was incubated for $24 \mathrm{~h}$ at $35^{\circ} \mathrm{C} \pm 2{ }^{\circ} \mathrm{C}$. Using a spectrophotometer (Beckman, $\mathrm{DU}^{\circledR} 530$ ) with the wavelength set at $580 \mathrm{~nm}$ and a $10 \mathrm{~mm}$ absorption cell, the broth containing the microorganism was diluted to achieve a suspension turbidity of $25 \pm 2 \%$ (transmittance) using the same sterile broth solution as for the blank. From this standardised suspension, $1.0 \mathrm{~mL}$ aliquots were added to each $100 \mathrm{~mL}$ of BHI agar $\left(\mathrm{BD}^{\circledR}\right)$ at $47^{\circ} \mathrm{C} \pm 1^{\circ} \mathrm{C}$ and used as the inoculum layer in the plate.

\section{Agar diffusion bioassay}

The bioassay described previously followed the 3 x 3 parallel line assay design (three doses of the standard and three doses of the sample in each plate), with six plates for each assay, according to the Brazilian Pharmacopoeia (F. BRAS., 2010). The agar was composed of two separate layers. The BHI agar $(20 \mathrm{~mL})$ was poured into a $100 \mathrm{~mm}$ x $20 \mathrm{~mm}$ Petri dish as a base layer. After solidification of this layer, a $5 \mathrm{~mL}$ portion of the inoculated BHI agar was poured onto the base layer.

In each plate, a template was placed on the surface of the inoculated medium. Three alternating holes were filled with $200 \mu \mathrm{L}$ of the reference solution (S1, S2 and S3), and the other three holes were filled with the sample solutions (T1, T2 and T3). Six plates were used in each assay. The plates were incubated at $35 \pm 1{ }^{\circ} \mathrm{C}$ under aerobic conditions for 18 hours. The diameters $(\mathrm{mm})$ of the zones of inhibition were carefully measured using a digital calliper (Mitutoyo ${ }^{\circledR}$ IP 65) (Figure 2). All experiments were performed in a biological safety cabinet, and the infected material was decontaminated before being discarded.

\section{Method validation}

The method was validated by the determination of linearity, precision and accuracy (USP, 2008; Marona, Schapoval, 1998; Gomes, Salgado, 2007; Salgado, Lopes, Lucchesi, 2006; Moreno, Salgado, 2007; Salgado, Tozo, 2007; Lopes, Salgado, 2010; Cazedey, Salgado, 2011; Paim et al., 2011; ICH, 2005; AOAC, 2005).

\section{Linearity}

To assess the validity of the assay, three doses of the standard and three doses of the sample were used. The linearity was evaluated by linear regression analysis, which was calculated using the least squares method.

\section{Precision}

The precision of the method was determined by repeatability (intra-assay) and the intermediate precision (inter-assay) and was expressed as the relative standard deviation (RSD). The repeatability was verified by assaying samples of $\mathrm{CHX}$ digluconate in aqueous solution, at the same concentration, within one day and under the same experimental conditions. The intermediate precision was evaluated by comparing the assay results from three different days.

\section{Accuracy}

Accuracy was determined by adding 3 concentrations, which covered the specified range. Aliquots of precisely 500,1000 and $1500 \mu \mathrm{L}$ of the standard solution $(20 \%)$ were transferred into $10 \mathrm{~mL}$ volumetric flasks, and diluted with water to give final concentrations of $1.5,2.5$ and $3.5 \%$, respectively. The percentage recovery of the CHX digluconate standard was calculated using the equation proposed by the AOAC (2005). 


\section{Calculation of potency}

To calculate the activity of $\mathrm{CHX}$ digluconate in aqueous solution, the Hewitt [38] equation was used. The assays were statistically analysed using the linear parallel model and regression analysis and verified using analysis of variance (ANOVA) (USP, 2008; Marona, Schapoval, 1998; Salgado, Gomes, Salgado, 2006; Lopes, Lucchesi, 2006; Moreno, Salgado, 2007; Salgado, Tozo, 2007; F. BRAS., 2010; Lopes, Salgado, 2010; Cazedey, Salgado, 2011; Paim et al., 2011).

\section{RESULTS AND DISCUSSION}

The development and validation of analytical methods for the determination of active ingredients in medicines is very important for quality control and patient safety. When choosing an analytical method for use in routine quality control, the analyst must consider cost, complexity, required time, availability of equipment and reagents, purity, quantity of the sample and the generation of residues (ICH, 2005; Salgado, Lopes, Lucchesi, 2006; Moreno, Salgado, 2007).

Moreover, the development and validation of analytical methods to determine potency, such as microbiological assays, have recently received considerable attention, mainly from regulatory agencies, because of their importance in pharmaceutical analysis (Mendez et al., 2005; Moreno, Salgado, 2007; Salgado, Tozo, 2007; Lopes, Salgado, 2010; Cazedey, Salgado, 2011). Microbiological assays have the potential to prevent the possible loss of activity, while physicochemical methods do not prevent the loss of the antimicrobial potency (USP, 2008).

For this reason, a microbiological assay was proposed as a suitable method for the determination of CHX digluconate in aqueous solution.

The experimental conditions were tested and adjusted to accurately determine the performance of the assay. Some parameters were tested previously to establish the described conditions and shown in Table I. The strain of Staphylococcus aureus that was used, ATCC 25923, appears to be an appropriate test microorganism because of its susceptibility to CHX-D and its capacity to form sharply defined zones of growth inhibition, allowing for precise measurements.

The potency of an antibiotic may be demonstrated under suitable conditions by comparing the inhibition of growth of a microorganism caused by known concentrations of the antibiotic and a reference standard (USP, 2008; F. BRAS., 2010; EP, 2011).
TABLE I - Tested conditions to establish the parameters for microbiological assay of $\mathrm{CHX}$ digluconate

\begin{tabular}{ll}
\hline Parameter & Condition \\
\hline Standard curve $(\mu \mathrm{g} / \mathrm{mL})$ & $1.5,3.0,6.0 \% ; 0.25,1.0,4.0 \%$ \\
& and 0.5, 1.5, 4.5\% \\
Diluents & Buffer solution $\mathrm{pH} 6.0$ and \\
& $\mathrm{pH} 8.0$ \\
& Purified water \\
Inoculum (\%) & 0.5 and 1.0 \\
Microorganism & Bacillus subtilis ATCC 9372 \\
& Staphylococcus aureus ATCC \\
& 25923 \\
Culture media & Mueller Hinton agar \\
& Brain Heart Infusion (BHI) \\
& agar \\
\hline
\end{tabular}

\section{Method validation}

In this experimental work, a $3 \times 3$ design was used, using three concentrations of both a standard and sample solution, according to the procedure described in the Brazilian Pharmacopoeia (F. BRAS., 2010). The calculation assumes a direct relationship between the observed diameter of the zone of inhibition and the logarithm of the applied dose. The growth inhibition zones of aqueous solutions of CHX digluconate and the reference substance are shown in Figure 2.

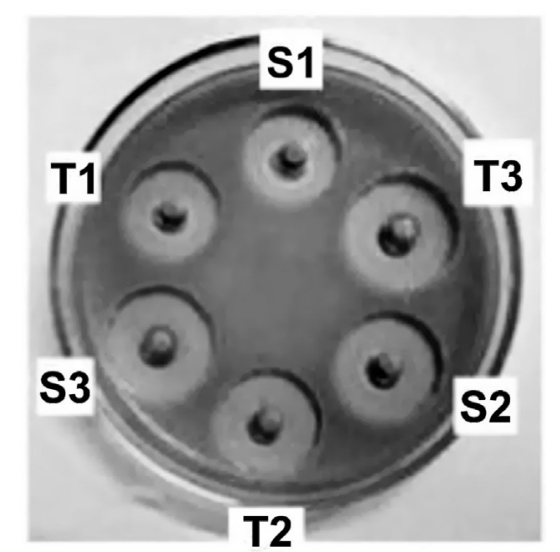

FIGURE 2 - An agar diffusion assay using a strain of $S$. aureus ATCC 25923 as the test microorganism. The chlorhexidine digluconate reference solutions are at concentrations of 0.5 (S1), 1.5 (S2) and $4.5 \%$ (S3) and the chlorhexidine digluconate samples are at concentrations of 0.5 (T1), 1.5 (T2) and $4.5 \%$ (T3).

Table II gives the results, represented as the diameters of the zones of inhibition, for $\mathrm{CHX}$ digluconate in aqueous solution. 
TABLE II - Diameters of the zones of inhibition for CHX digluconate in aqueous solution and the reference solution, obtained using a standard curve

\begin{tabular}{lccc}
\hline Concentration (\%) & Range of zone size, $\mathbf{~ m m}$ & $\begin{array}{c}\text { Means diameters of growth } \\
\text { inhibition zones } \mathbf{a}, \mathbf{~ m m}\end{array}$ & RSD\% \\
\hline 0.5 & $19.27-19.32$ & 19.30 & 0.9 \\
1.5 & $20.79-20.84$ & 20.81 & 1.0 \\
4.5 & $22.33-22.39$ & 22.37 & 1.1 \\
\hline
\end{tabular}

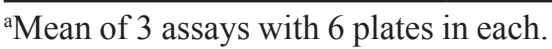

The calibration curve for CHX digluconate in aqueous solution was constructed by plotting the zone diameter $(\mathrm{mm})$ versus the log of the concentration $(\%)$ and showed good linearity in the 0.5 to $4.5 \%$ range.

The representative linear equation for $\mathrm{CHX}$ digluconate was $y=1.3972 \operatorname{Ln}(x)+20.26$, where $x$ is the log dose and $y$ is the zone diameter. The coefficient of regression was 0.9999 , which is highly significant for the method. According to the Brazilian and the United States Pharmacopoeias (USP, 2008; F. BRAS., 2010), if a parallel-line model is chosen, the two log dose-response lines of the preparations to be examined, as well as that of the reference preparation, must be parallel, and they must be linear over the range of doses used in the calculation. These conditions must be verified by validity tests for a given probability, usually $p=0.05$. The assays were validated by analysis of variance (ANOVA), as described in those official codes. There were no deviations from parallelism or linearity in the obtained results $(p<0.05)$ (Table III).

TABLE III - Analysis of variance of determination of CHX digluconate by bioassay

\begin{tabular}{lcc}
\hline Parameters & $\boldsymbol{F}$ calc & $\boldsymbol{F}$ tab \\
\hline Linear regression & $154264.9^{*}$ & 4.24 \\
Linearity deviation & 3.159 & 3.38 \\
Parallelism & 0.182 & 4.24 \\
\hline
\end{tabular}

$* \mathrm{p}<0.05)$.
The method precision in terms of repeatability (intra-assay) shows a mean R.S.D. of $2.03 \%$, indicating good intra-day precision for the method. The intermediate precision shows a mean R.S.D. of $2.94 \%$.

The mean accuracy was $99.03 \%$, and the R.S.D. was $1.32 \%$ (Table IV), which confirms the ability of the method to accurately determine the concentration of CHX digluconate in aqueous solution and shows that the results obtained from the bioassay were close to the true concentrations of the samples.

\section{Calculation of potency}

The CHX digluconate activity ranged from 92.52 to $92.61 \%$, with an R.S.D. value of $0.1 \%$. This value is acceptable because the American Pharmacopoeia (USP, 2008) allows for variations of up to $10 \%$ for mouth rinse. Moreover, CHX digluconate is a non-sterile product that is indicated for external use only, which allows a $10 \%$ variation (USP, 2008; EP, 2011). The low R.S.D. values that were obtained confirm that the proposed method can generate reproducible results with little variation between independent assays.

The quantification of ingredients in antiseptics using chemical methods, such as HPLC and UV spectrophotometry, although precise, cannot provide a true indication of biological activity. Therefore, bioassays play an essential role in the manufacturing and quality control of antibiotics. This study confirms the validity of using bioassays for the quality control of antiseptic medicines

TABLE IV - Accuracy of the microbiological assay of CHX digluconate

\begin{tabular}{lcccc}
\hline \multirow{2}{*}{ Run } & \multicolumn{4}{c}{ Amount of standard (\%) } \\
\cline { 2 - 5 } & Added (\%) & Recovered (\%) & Recovery (\%) & RSD (\%) \\
\hline R1 & 5.00 & 4.93 & 98.6 & 1.32 \\
R2 & 10.00 & 9.80 & 98.0 & \\
R3 & 15.00 & 15.07 & 100.5 & \\
\hline
\end{tabular}

${ }^{a}$ Mean of 3 assays 
this for antiseptic medicines, and this technique still demands considerable skill and expertise to ensure success (Vaugher, Breier, Schapoval, 2006; Lopes, Salgado, 2010; Cazedey, Salgado, 2011; Paim et al., 2011). Although biological assays might have a high variability, the analysis of the results demonstrates that the proposed method might be very useful for determination of the potency of $\mathrm{CHX}$ digluconate in aqueous solution.

The results obtained in this study were very satisfactory, and the validation demonstrated that microbiological assays are a good alternative methodology for the pharmaceutical analysis of CHX digluconate in aqueous solution. It is a useful analytical tool in conjunction with or substitution for a physicochemical method.

\section{CONCLUSION}

The results indicated that the microbiological assay demonstrated excellent linearity, precision and accuracy at concentrations ranging from 0.5 to $4.5 \%$. Therefore, it is an acceptable alternative method for the routine quality control of CHX digluconate in aqueous solution. The method uses simple reagents, requires minimal sample preparation, produces no toxic residues and there is no sophisticated equipment required, supporting its use in routine analysis.

\section{ACKNOWLEDGEMENTS}

The authors are grateful to Maria de Fátima Rodrigues for technical support and to Dr. Greici C. G. Tozo, Rioquimica Ltda (São José Rio Preto, Brazil) for providing the standard of CHX. CNPq-Brazil, CAPES Brazil and PADC - FCF - Araraquara Program supported this work.

\section{REFERENCES}

ABAD-VILLAR, E.M.; ETTER, S.F.; THIEL, M.A.; HAUSER, P.C. Determiantion of chlorhexidine digluconate and polyhexamethylene biguanide in eye drops by capillary electrophoresis with contactless conductivity detection. Anal. Chem. Acta., v.561, p.133-137, 2006.

AOAC INTERNATIONAL. Official methods of analysis. 18ed. Gaithersburg: AOAC INTERNATIONAL, 2005.

BELOW, H.; LEHAN, N.; KRAMER, A. HPLC determination of the antiseptic agent chlorhexidine and its degradation products 4-chloroaniline and 1-chloro-4-nitrobenzene in serum and urine. Microchim. Acta, v.146, p.129-135, 2004.
BONAZZI, D.; ANDRISANO, V.; GATTI, R.; CAVRINI, V. Analysis of pharmaceutical creams: a useful approach base on solid-phase extraction (SPE) and UV spectrophotometry. J. Pharm. Biomed. Anal., v.13, p.1321-1329, 1995.

BRITISH PHARMACOPOEIA. London: Her Majesty's Stationery Office, 2010. p.467-470, p.2485-2488.

BROUGHAM, L.R.; CHENG, H.; PITTMAN, K.A. Sensitive high-performance liquid chromatographic method for the determination of chlorhexidine in human serum and urine. J. Chromatogr., v.383, p.365-373, 1986.

BUXBAUM, A.; KRATZER, C.; GRANINGER, W.; GEORGOPOULOS, A. Antimicrobial and toxicological profile of the new biocide Akacid plus. J. Antimicrob. Chemother.,v.58, p.193-197, 2006.

CAZEDEY, E.C.L.; SALGADO, H.R.N. Development and validation of a microbiological agar assay for determination of orbifloxacin in pharmaceutical preparations. Pharmaceutics, v.3, p.572-580, 2011.

CONE, R.A.; HOEN, T.; WONG, X.; ABUSUWWA, R.; ANDERSON, D.J; MOENCH, T.R. Vaginal microbicides: detecting toxicities in vivo that paradoxically increase pathogen transmission. BMC Infect. Dis., v.6, p.1-16, 2006.

EUROPEAN PHARMACOPOEIA. 7.ed. Strasbourg: Council of Europe, 2011. p.1659-1663.

FARMACOPEIA BRASILEIRA. 5.ed. Brasília: ANVISA, 2010. p.258-270.

FIORENTINO, F.A.M.; CORREAA, M.A.; SALGADO, H.RN. Analytical methods for the determination of chlorhexidine: a review. Critical Rev. Anal. Chem., v.40, p.89-101, 2010.

GAFFNEY, M.H.; COOKE, M.J. Improved method for the determination of chlorhexidine in urine. Chromatogr., v.306, p.303-313, 1984.

GALICE, M.D.; BONACORSI, C.; SOARES, V.C.G.; RADDI, M.S.G.; FONSECA, L.M. Effect of subinhibitory concentration of chlorhexidine on Streptococcus agalactiae virulence factor expression. Int. J. Antimicrob. Agents., v.28, p.143-146, 2006. 
GAVLICK, W.K. High-performance liquid chromatographic analysis of chlorhexidine and $p$-chloroaniline using a specialty column and a photodiode-array detector. $J$. Chromatogr., v.623, p.375-380, 1992.

GOMES, G.C.; SALGADO, H.R.N. Microbiological assay for determination of lomefloxacin in coated tablets. J. AOAC Int., v.89, p.1077-1079, 2006.

HÁ, Y.; CHEUNG, A.P. New stability-indicating high performance liquid chromatography assay and proposed hydrolytic pathways of chlorhexidine. J. Pharm. Biomed. Anal., v.14, p.1327-1334, 1996.

HAVLÍKOVÁ, L.; MATYSOVÁ, L.; NOVÁKOVÁ, L.; HAJKOVÁ, R.; SOLICH, P. HPLC determination of chlorhexidine gluconate and p-chloroaniline in topical ointment. J. Pharm. Biomed. Anal., v.43, p.1169-1173, 2007.

HEWITT, W. Microbiological assay for pharmaceutical analysis: a rational approach. Boca Raton: Interpharm/CRC Press, 2003. p.97-115.

INTERNATIONAL CONFERENCE ON HARMONIZATION. ICH. Topic Q2(R1) validation of analytical procedures: text and methodology. Geneva: ICH Steering Committee, 2005.

IZUMOTO, S.; MACHIDA, Y.; NISHI, H.; NAKAMURA, K.; NAKAI, H.; SATO, T. Chromatography of crotamiton and its applications to the determination of active ingredients in ointment. J. Pharm. Biomed. Anal., v.15, p.1457-1466, 1997.

JENSEN, J.E.; CHRISTENSEN, F. A study of the elimination of chlorhexidine from the oral cavity using a new spectrophotometric method. J. Periodont. Res., v.6, p.306311,1971 .

LAM, Y.W.F.; CHAN, D.C.N.; RODRIGUEZ, S.; LINTAKOON, J.H.; LAM, T-H. Sensitive high-performance liquid chromatographic assay for the determination of chlorhexidine in saliva. J. Chromatogr., v.612, p.166-171, 1993.

LOPES, C.C.G.O.; SALGADO, H.R.N. Development and validation of a stability-indicative agar diffusion assay to determine the potency of linezolid in tablets in the presence of photodegradation products. Talanta, v.82, p.918-922, 2010.
MARONA, H.R.N.; SCHAPOVAL, E.E.S. Desarrollo de análisis microbiológico para la determinación de esparfloxacino en polvo y en comprimidos de $200 \mathrm{mg}$. Inf. Tecnol., v.9, p.251-254, 1998.

MARTINDALE: the complete drug reference. 36ed. Pharmaceutical Press, 2009. p.1635-1638.

MENDEZ, A.S.L.; WEISHEIMER, V.; OPPE, T.P.; STEPPE, M.; SCHAPOVAL, E.E.S. Microbiological assay for the determination of meropenem in pharmaceutical dosage form. J. Pharm. Biomed. Anal., v.37, p.649-653, 2005.

MIRIBEL, L.; BRAZIER, J.L.; COMET, F.; LECOMPTE, D. Gas-liquid chromatographic determination of chlorhexidine in pharmaceutical formulations. J. Chromatogr., v.268, p.321-328, 1983.

MORENO, A.H.; SALGADO, H.R.N. Microbiological assay for ceftazidime injection. J. AOAC Int., v.90, p.1379-1382, 2007.

PAIM, C.S.; F'UHR, F.; BARTH, A.B.; GONÇALVES, C.E.I.; NARDI, N.; STEPPE, M.; SCHAPOVAL, E.E.S. Gemifloxacin mesylate (GFM) stability evaluation applying a validated bioassay method and in vitro cytotoxic study. Talanta, v.83, p.1774-1779, 2011.

PESONEM, T.; HOLMALAHTI, J.; POHJOLA, J. Determination of chlorhexidine in saliva using highperformance liquid chromatography. J. Chromatogr. B. Biomed. Appl., v.665, p.222-225, 1995.

SALGADO, H.R.N.; LOPES, C.C.G.O.; LUCCHESI, M.B.B. Microbiological assay of gatifloxacin in pharmaceutical formulations. J. Pharm. Biomed. Anal., v.40, p.443-446, 2006.

SALGADO, H.R.N.; TOZO, G.C.G. Microbiological assay for cefoxitin sodium in dosage form. J. AOAC Int., v.90, n.2, p.452-455, 2007.

SCHMIDT, C.A.; CARAZZO, M.; LAPORTA, L.V.; BITTENCOURT, C.F.; SANTOS, M.R.; FRIEDRICH, M. Development and validation of an agar diffusion assay for determination of ceftazidime in pharmaceutical preparations. J. AOAC Int., v.91, p.59-66, 2008. 
SOLANO, A.G.R.; PREIRA, L.M.C.S.; LEONEL, M.F.V.; NUNAN, E.A. Development of agar diffusion method for dosage of gramididin. Braz. J. Pharm. Sci., v. 47, p. 555$572,2011$.

SOUZA, M.J.E.; ROLIM, C.M.B.; MELO, J.; SOUZA-FILHO, P.S.; BERGOLD, A.M. Development of a microbiological assay to determine the potency of ceftiofur sodium powder. J. AOAC Int., v.90, p.1724-1728, 2007.

UNITED STATES PHARMACOPOEIA. 31ed. Rockville: The United States Pharmacopeia Convention, 2008. p.17311733.

THOMAS, L.; MAILLARD, J.Y.; LAMBERT, R.J.W.; RUSSELL, A.D. Development of resistance to chlorhexidine diacetate in Pseudomonas aeruginosa and the effect of a residual concentration. J. Hosp. Infect., v.46, p.297-303, 2000.
USUI, K.; HISHINUMA, T.; YAMAMGUCHI, H.; TACHIIRI, N.; GOTO, J. Determination of chlorhexidine (CHD) and nonylphenolethoxylates (NPEOn) using LC-ESI-MS method and application to hemolyzed blood. J. Chromatogr. $B$, v.831, p.105-109, 2006.

VAUGHER, L.C.; BREIER, A.R.; SCHAPOVAL, E.E.S. Microbiological assay for the determination of telithromycin in tablets. J. AOAC Int., v.89, p.1398-1402, 2006.

VRIES, J.; RUBEN, J.; ARENDS, J. Determination of chlorhexidine in saliva and in aqueous solutions. Caries Res., v.25, p.410-414, 1991.

Received for publication on: $08^{\text {th }}$ May 2012 Accepted for publication on: $12^{\text {th }}$ December 2012 